\title{
POZNAŃ Z PERSPEKTYWY: KLASA I PŁEĆ SPOŁECZNO-KULTUROWA JAKO KATEGORIE KSZTAŁTUJĄCE OBRAZ MIASTA W PISARSTWIE WSPOMNIENIOWYM
}

\author{
MAGDALENA BEDNAREK ${ }^{1}$ \\ (Poznań)
}

\begin{abstract}
Słowa kluczowe: autobiografia, mieszczaństwo, Poznań, lumpenproletariat, klasa, płeć społeczno-kulturowa
\end{abstract}

Keywords: autobiography, burgess, Poznań, lumpenproletariat, class, gender

\begin{abstract}
Abstrakt: Magdalena Bednarek, POZNAŃ Z PERSPEKTYWY. KLASA I PŁEĆ SPOŁECZNOKULTUROWA JAKO KATEGORIE KSZTAŁTUJĄCE OBRAZ MIASTA W PISARSTWIE WSPOMNIENIOWYM. „PORÓWNANIA” 11, 2012, Vol. XI, ss. 217-231, ISSN 1733-165X. Celem artykułu jest przedstawienie płci społeczno-kulturowej oraz klasy jako kategorii determinujących kształt podwójnego portretu (miasta i siebie), jaki pojawia się w literaturze wspomnieniowej o Poznaniu lat międzywojennych. Jak się okazuje określają one kształt miasta, jego wielkość, ale także zaludnienie i zagospodarowanie przestrzeni; decydują także o odmiennym usytuowaniu na jego tle podmiotu. Bohaterami artykułu staną się Przechadzki po Poznaniu lat międzywojennych, Ulicami mojego Poznania. Przechadzki z lat 1918-1939 Z. Zakrzewskiego, Grzeszne miasto M. Rataj. Ważnym kontekstem dla tych dwóch utworów będzie także pisarstwo wspomnieniowe P. Cegielskiej, A. Łuczaka, M. Mottego, T. Szulca, J. Waldorffa oraz M. Fornalskiej, A. Scheffel i S. Grzesiuka.
\end{abstract}

Abstract: Magdalena Bednarek, POZNAŃ FROM A PERSPECTIVE:CLASS AND GENDER AS CATEGORIES WHICH SHAPE THE IMAGE OF A CITY IN RECOLLECTION LITERATURE „PORÓWNANIA" 11, 2012, Vol. XI, pp. 217-231, ISSN 1733-165X. The aim of the article is to present gender and class as two categories that determine the double portrait (of the city and of the self) as observed in the interwar memoirs about Poznan. As it turns out, they play a pivotal part in description of the shape of the city, its size and the organisation of its space; they also arrange the way the self is situated within the city space. The main texts analysed in the article are two books by Z. Zakrzewski: Przechadzki po Poznaniu lat międzywojennych, Ulicami mojego

\footnotetext{
${ }^{1}$ Correspondence Address: magbed@amu.edu.pl
} 
Poznania. Przechadzki z lat 1918-1939 and M. Rataj's Grzeszne miasto. Other important works used as contexts are memoirs of P. Cegielska, A. Łuczak, M. Motte, T. Szulc, J. Waldorff, M. Fornalska, A. Scheffel and S. Grzesiuk.

\section{POZNAŃSKI GENIUS LOCI (POSZUKIWANY)}

Wyobrażeniowa mapa Polski tworzona przez teksty kultury, a w szczególności przez literaturę ${ }^{2}$, nie wydaje się zbyt rozległa ani zapełniona wieloma punktami. Kraków (np. awangardy), Warszawa (dwudziestolecia międzywojennego, Mirona Białoszewskiego), Gdańsk (Pawła Huelle i Stefana Chwina), Zakopane (przede wszystkim młodopolskie) to bardzo niewiele, reszta Polski to białe palmy. Jeśli jednak pisarzy miasta - jak twórców tych wyobrażonych w literaturze przestrzeni nazywa polski redaktor Atlasu literatury ${ }^{3}$ - szukać nie tylko w literaturze wysokoartystycznej, wówczas znaleźć się na niej może Wrocław (Marka Krajewskiego), uwspółcześniony Kraków (Grzegorza Turnaua) - lub Poznań (Małgorzaty Musierowicz).

Innym tropem uzupełniania wyobrażeniowej mapy może być uwzględnienie piśmiennictwa wspomnieniowego, świadectw, jakie o mieście dali jego mieszkańcy. Z tej perspektywy Poznań (jedna z białych plam w Atlasie literatury) okazuje się obdarzony swoistym genius loci, który decyduje o jego tożsamości mimo zmieniających się warunków historycznych, politycznych, społecznych etc. - co zauważył Janusz Ziółkowski, komentując opinie respondentów dwóch konkursów socjologicznych (z 1928 oraz 1964), mających na celu zbadanie tego miasta jako całości społecznej ${ }^{4}$.

Obecność genius loci Poznania jest także bardzo wyrazista w pisarstwie dwóch pamiętnikarzy - Maurycego Mottego, którego Przechadzki po mieście (1888-1891) Elżbieta Rybicka uznała za źródło pasaży literackich ${ }^{5}$ (co może stanowić swoisty dowód inspirującej mocy ducha stolicy Wielkopolski) oraz Zbigniewa Zakrzewskiego, który rozpoczyna pisanie swoich książek wspomnieniowych w latach 60 . XX wieku, wyraziście (bo tytułami) nawiązując do swego poprzednika. Stolica Wielkopolski ukazana w Przechadzkach po Poznaniu lat międzywojennych (1983),

2 Posługuję się pojęciem Malcolma Bradbury'ego, zob. M. Bradbury, Wstęp. w: Atlas literatury. Red. M. Bradbury. Przeł. A. Błasiak, D. Gostyńska, M. Jędrzejak, I. Libucha. Warszawa 2002, s. 10.

${ }^{3}$ Ibidem, s. 336.

${ }^{4}$ F. Znaniecki, J. Ziółkowski, Czym jest dla ciebie miasto Poznań? Dwa konkursy 1928/1964. Warszawa 1984, s. 18.

${ }^{5}$ E. Rybicka, Modernizowanie miasta. Zarys problematyki urbanistycznej w nowoczesnej literaturze polskiej. Kraków 2003, s. 163 i nast. 
Wspominam Poznań (1986) oraz Ulicami mojego Poznania (1985)6 Zakrzewskiego nie różni się wiele od tej przedstawionej w Przechadzkach po mieście, choć ich publikację dzieli ponad wiek. Poznań wyłaniający się z tych wspomnień, ale także ze stereotypów, to miasto dostatnie, porządne i praworządne, o solidnych fundamentach w wartościach mieszczańskich, takich jak rodzina, zaradność, pragmatyzm, rzetelność.

Na ile jednak genius loci determinuje jeden wspólny głos, a na ile natomiast jest on generowany przez wcześniejsze teksty o mieście? Na to pytanie oczywiście nie sposób dać odpowiedzi, można jednak zastanowić się, jakie czynniki decydują o jednolitości obrazu miasta, innymi słowy: czyja narracja o nim zdominowała społeczną wyobraźnię. Wydaje się, że zbieżność narracji Mottego i Zakrzewskiego ma swe źródło w perspektywie, którą podzielają. Perspektywa ta (mieszczańskointeligencka i androcentryczna), choć uświęcona tradycją, a przez to wydawałoby się jedyna, jest jednak bardzo partykularna, co może uświadomić konfrontacja twórczości Zakrzewskiego ze wspomnieniami Marii Rataj - oboje w podobnym momencie opisują Poznań lat międzywojennych. Wydane w 1962 r. Zaułki grzesznego miasta ${ }^{7}$ burzą jednak mit dostatniego i praworządnego miasta za sprawą wyjątkowej perspektywy, którą jego autorka przyjęła świadomie i prowokacyjnie: punktu widzenia kobiety i proletariuszki.

\section{PIĘTNO CZASÓW, KLASY I PŁCI}

The painter Henri Matisse once remarked that all art bears the imprint of its historical epoch, but that great art is that in which this imprint is most deeply marked ${ }^{8}$.

Poznanianka, nazywając siebie Gawrychem, wyposaża czytelnika/czytelniczkę w swoisty klucz do swojej tożsamości: ofiary nierówności społecznych (i niewydolnego systemu opieki, społecznej ${ }^{9}$ ), zachowującej jednak godność osobistą. Nie bez znaczenia jest także literacka proweniencja tego samookreślenia, od razu sytuująca sympatię czytelniczą po jedynej słusznej stronie - skrzywdzonego

6 Wszystkie cytaty na podstawie wydań: Z. Zakrzewski, Przechadzki po Poznaniu lat międzywojennych. Poznań 1983 (PPP); Z. Zakrzewski, Wspominam Poznań. Poznań 1986 (WP); Z. Zakrzewski, Ulicami mojego Poznania. Poznań 1985 (UMP). Oznaczenia w nawiasie po cytacie.

${ }^{7}$ Drugie wydanie ukazało się w roku 2007 pod tytułem Grzeszne miasto (Poznań) i stanowi obszerniejszy niż wcześniejsza publikacja wybór z rękopisu Rataj (pseudonim). Wszystkie cytaty na podstawie tego wydanie, lokalizacja w nawiasie za cytatem oznaczona skrótem GM.

8 Terry Eagleton, Marxism and Literary Criticism, London and New York 2002, s. 3.

${ }_{9}^{9}$ Niesprawność opieki społecznej znajduje potwierdzenie w wypowiedziach respondentów konkursu z 1928 r. Zob. F. Znaniecki, J. Ziółkowski, op. cit., s. 110. 
dziecka ulicy. Tożsamość ta wzbogacona jest jednak świadomością klasową: jako proletariuszkę kształtuje ją antagonistyczny stosunek wobec mieszczaństwa oraz jego przewagi ekonomicznej i wynikająca stąd opresja.

Poznanianka zwraca także uwagę na kolejny poziom wykluczenia i dyskryminacji związany z płcią. Jako proletariuszka narażona jest nie tylko na wyzysk ekonomiczny, ale także przemoc seksualną, o czym przekonała ją praca w charakterze pomocy domowej, podjęta zaraz po ukończeniu szkoły sześcioklasowej. Awanse syna pracodawców skończyły się próbą gwałtu - i utratą posady (GM, s. 214-215). Taki kierunek krytyki stosunków społecznych i ekonomicznych w Poznaniu lat międzywojennych znajduje potwierdzenie $w$ wypowiedziach respondentów konkursu przeprowadzonego przez Floriana Znanieckiego w 1928 roku:

Powiadam, że biedne kobiety w ogóle nazwać można jednym słowem: białe niewolnice. Co ta kobieta ma za prawa? Panny chcą mieć gdzieś pracę [...] Jeżeli chce mieć pracę, musi się z tym pogodzić, że stawia zarazem swoje ciało do dyspozycji na zachcianki swego pryncypała ${ }^{10}$.

- pisał poznański robotnik. Maria Rataj wielokrotnie zauważa także odmienne standardy moralne obowiązujące kobiety i mężczyzn, także z tej samej klasy społecznej: "To chłopom wolno mieć inne kobiety, a gdy one zrobią tak samo, to źle" (GM, s. 83). Podmiot wyłaniający się z tych wspomnień działa jednak na przekór społeczno-kulturowym normom zachowań związanym z płcią: Rataj to diablica, dziewczyna-kozak, która, obrażana, zamiast szlochać, używa pięści (GM, s. 169). Można więc stwierdzić, że "ja” w Zaułkach grzesznego miasta wyłania się w toku nieustannych antagonistycznych starć z porządkiem społecznym (kłopoty w szkole, wagary, praca od szóstego roku życia, szpital jako miejsce doświadczania luksusu, nieślubne potomstwo), podczas gdy u Zakrzewskiego kształtuje się ono w harmonii z tymże porządkiem: edukacja, praca, życie rodzinne przychodzą (ponownie) w sposób oczywisty i naturalny. Warto zauważyć, że opozycja ta znajduje potwierdzenie $\mathrm{w}$ innych wspomnieniach: męskich i mieszczańsko-inteligenckich Tadeusza Szulca, Jerzego Waldoffa ${ }^{11}$ oraz kobiecych i proletariackich - Aurelii Scheffel ${ }^{12}$.

${ }^{10}$ F. Znaniecki, J. Ziółkowski, op. cit., s. 163.

11 Zob. T. Szulc, W Poznaniu i w koto niego. Wspomnienia poznańskiego lekarza, Poznań 1995; J. Waldorff, Fidrek. Warszawa 1989. Cytaty na podstawie powyższych wydań, oznaczenia w nawiasach za cytatem (WPL oraz F).

12 Aurelia Scheffel to łodzianka urodzona w 1928, wywodząca się z robotniczej niemieckiej rodziny. Podobnie jak Rataj doświadcza ona braku wsparcia rodziców-analfabetów w nauce, wagaruje, przyznaje się także do nagannych zachowań moralnych (oszustwo, kłamstwo), pracuje od siódmego roku życia, doświadcza pobytu w szpitalu, a także skora jest do butności - satysfakcji upatruje w posiadaniu blizny większej niż chłopak. W przeciwieństwie do poznanianki jednak Scheffel wychowuje się w kochającej się, pełnej i szczęśliwej rodzinie. Nie wspomina ona także o uciekaniu się do 
O ile Rataj tematyzuje nie tylko swoją tożsamość, ale i specyfikuje społeczną przestrzeń, z której wydobywa się jej głos, Zakrzewski tej pierwszej nie problematyzuje, a drugą czyni nieprzejrzystą, pisząc we wstępie do Wspominam Poznań:

Dziejopisarstwo nie powinno przybierać wyłącznie wysokiego tonu, prezentując głównych aktorów i koleje wielkiej polityki. Warto dowiedzieć się jak upływał zwyczajny dzień, jakie aspiracje ożywiały zwykłych zjadaczy chleba, jaki był ich sposób myślenia (WP, s. 6).

Takim przeciętnym człowiekiem nie jest jednak autor Wspominam Poznań. I to z dwóch przynajmniej powodów. Przede wszystkim, wbrew kilkakrotnie przywoływanemu toposowi skromności, jest postacią wybitną - pełni funkcje doniosłe społecznie (profesor, rektor Akademii Ekonomicznej), od wczesnej młodości przyjmuje rolę strażnika wartości (działając w różnych stowarzyszeniach). Samoświadomy i autonomiczny, dążący do samorealizacji i perfekcji na różnych polach, a przy tym humanista, miłośnik opery i teatru, jest reprezentatywny dla formacji inteligenckiej - wysokie standardy (dotyczące chociażby działalności społecznej, ciekawości poznawczej, uczestnictwa w życiu kulturalnym, pracy zawodowej), jakie narzuca sobie Zakrzewski, uznaje on za powszechnie obowiązujące - ale są takimi tylko w jego środowisku (co ponownie potwierdzają wspomnienia Tadeusza Szulca i, w części, Jerzego Waldorffa). I tu kryje się drugi argument przemawiający za nieprzeciętnością perspektywy Zakrzewskiego. Jakkolwiek chce on przedstawić swój punkt widzenia jako uniwersalny, pozostaje on uwarunkowany jego przynależnością klasową i płcią społeczno-kulturową. "Ja", które Zakrzewski kreuje na kartach wspomnień, ogranicza się w zasadzie do czynności umysłowych oraz działalności na polu społecznym - utożsamiając tym samym ideał obywatela polis. Doświadczenia związane z biologicznymi aspektami jego egzystencji nie istnieją - warto dla porównania wspomnieć, że (starsza o pokolenie) Paulina Cegielska, reprezentująca mniej więcej tę samą sferę społeczną, konstruuje obszerne opisy smaków, podobnie Alojzy Andrzej Łuczak (młodszy o pokolenie syn robotnika) wielokrotnie wspomina dojmujące uczucie głodu. Zakrzewski jest wstrzemięźliwy także w relacjonowaniu swojego życia prywatnego („O domu rzekło się aż za dużo..." (WP, s. 319) i emocjonalnego. Zgodnie z tym samym wzorcem zachowuje się Cegielska oraz Szulc. Wydaje się więc, że skrajna dyskrecja w sprawach osobistych jest nie tylko charakterystyczna dla pewnej generacji autorek literatury wspomnieniowej, co zauważyła Tatiana Czerska13, ale i dla pisarzy określonej generacji i pochodzenia społecznego. $Z$ kolei ograniczenie autobiogra-

przemocy fizycznej czy kradzieży. Zob. A. Scheffel, Lodz - historia/e. Wspomnienia-epizody z mojego życia. Przeł. D. Czuczwara, M. Półrola. Łódź 2008.

${ }^{13}$ Zob. T. Czerska, Między autobiografia a opowieścia rodzinną. Kobiece narracje osobiste w Polsce po 1944 roku w perspektywie historyczno-kulturowej. Szczecin 2011, s. 110. 
ficznego „ja" do sfery wolicjonalnej oraz umysłowej jawi się jako związane w równym stopniu z genderem, co z przynależnością klasową.

Zakrzewski i Rataj, kreując swoją tożsamość, a zarazem perspektywę poznawczą i narracyjną, przyjmują całkowicie odmienne strategie. Autor Ulicami mojego Poznania nie problematyzuje swojej pozycji jako medium - co po części znajduje uzasadnienie $\mathrm{w}$ wyraziście przedmiotowym charakterze jego pierwszej oraz trzeciej książki, widocznym tak w tytule, jak i podporządkowaniu kompozycji kategoriom przestrzennym. Inna nieco sytuacja daje się zauważyć we Wspominam Poznań, gdzie dominuje porządek biograficzny ${ }^{14}$, a głównym tematem pozostają (tym razem wbrew tytułowi) losy autora, co prowokuje pytanie o tożsamość owego "ja". Podmiot wytwarzany w tej autobiograficznej narracji jawi się jako tyleż indywidualny, co (paradoksalnie) reprezentatywny i uniwersalny: mieszczańsko-inteligencki i męski. Rataj natomiast podkreśla specyficzność swojej pozycji, wielokrotnie i wprost próbując określić siebie w różnych kategoriach.

\title{
DWA MIASTA
}

\begin{abstract}
Wygląda na to, że w każdym mieście są dwa miasta: jedno, które odpowiada starannie wyrysowanym na planach przebiegom ulic, w których życie jest ściśle regulowane administracyjno-komunikacyjnymi dyrektywami, i drugie - które odsłania się dopiero uważnemu spojrzeniu, w którym wspomniane regulacje ulegają znamiennym przemianom. [...] Żaden z tych kształtów miasta nie ma do niego prawa wyłączności... ${ }^{15}$
\end{abstract}

Kategorie płci społeczno-kulturowej oraz klasy generują różnice w obrazie Poznania, różnice niekiedy tak duże, że choć Zakrzewski i Rataj opisują miasto, w którym żyli równocześnie (w latach międzywojennych), a spisują swoje wspomnienia w niewielkim odstępie czasowym ${ }^{16}$ (publikacje dzielą już, co istotne, dwie dekady), wydaje się, że to dwa różne miasta. Konstrukcja podmiotu we wspomnieniach Rataj i Zakrzewskiego pociąga za sobą różne sposoby prezentowania Poznania, który w obu tekstach pozostaje bynajmniej nie drugoplanowym, a istotnym i aktywnym (bo kształtującym podmiot) bohaterem. Zakrzewski już tytułami swoich książek sugeruje flâneurowski charakter poznania i narracji. Niespieszny

14 Stąd pojawiają się tam także epizody niezwiązane z rodzinnym miastem w ogóle - wakacje spędzane u okolicznych ziemian, w Paryżu, Włoszech, wojenna poniewierka od Francji po Wieniawę pod Radomiem. Podobnie dzieje się w spisywanym w latach 60. XX wieku Z moich wspomnień. Przechadzki po mieście (Poznań 1997, w tekście oznaczane ZMW) Pauliny Cegielskiej, która opisuje także wyjazdy wakacyjne do Lądka Zdroju czy do Berlina.

${ }_{15}$ T. Sławek, Miasto. Próba zrozumienia, w: Miasto w sztuce - sztuka miasta. Red. E. Rewers. Kraków 2010, s. 25.

16 Zakrzewski spisywał wspomnienia od wczesnych lat 60., Rataj skończyła pisać w 1956. 
i bezcelowy krok spacerowicza ma wyznaczać rytm i kierunek opowieści. Jeśli jednak przyjrzeć się Przechadzkom po Poznaniu lat międzywojennych, zorganizowane są one według porządku administracyjnego i intersubiektywnego - spacer zaczyna się od ścisłego centrum, (jak wskazały badania Ziółkowskiego, symbolu Poznania ${ }^{17}$ ) Starego Rynku, stamtąd promieniście rozchodzą się trasy ku kolejnym dzielnicom. Panoramiczna perspektywa przyjęta przez Zakrzewskiego pozwala mu na nieustanne przemieszczenia się od lat międzywojennych ku przeszłości i teraźniejszości:

Przed domkami budniczymi mieściła się jak pamiętam, studzienka z bamberką, ufundowana przez winiarza Goldenringa. Kobiety wiejskie siedzące na stopniach studzienki sprzedawały zioła lecznicze. [...] Po latach wojennej zawieruchy bamberka stanęła początkowo na Mostowej, zdobiąc Ogród Muzeum Etnograficznego [...]. Różne były losy białego orła jaśniejącego na ratuszowej wieży. Po raz pierwszy umieścił go tam w roku 1783 ślusarz Jakub Brang. Na kilka lat przed wojną światową zaborca skorzystał $\mathrm{z}$ drobnego remontu orła, by przy sposobności dodać mu pruską koronę. W kilka zaledwie miesięcy od radosnej chwili, kiedy to jak powszechnie mawiano wybuchła Polska, człowiek o stalowych nerwach, Leon Żuromski, siedząc okrakiem na czubku wieży, odpiłował ową koronę przy hucznym aplauzie zgromadzonego na dole tłumu. (PPP, s. 25)

Jeśli odwołać się do kategorii psychologicznych, Zakrzewski, konstruując swoje wspomnienia, częściej korzysta z pamięci semantycznej (odpowiedzialnej za gromadzenie informacji) niż epizodycznej (związanej z wydarzeniami, w których brało się udział) - stanowiącej podstawę pamięci autobiograficznej, jak uważa Tomasz Maruszewski ${ }^{18}$. Znajduje to potwierdzenie we wzmiankach poznaniaka o korzystaniu z notesów i zapisków, które pozwalały mu także relacjonować stosunkowo dokładnie repertuar operowy, teatralny, a nawet kinowy. Warto porównać tę technikę ze wspomnieniami Cegielskiej, która przecież także napisała "przechadzki" - ograniczają się one jednak w zasadzie tylko do śódmieścia z mikrocentrami (także kompozycyjnymi) w postaci kolejnych domowych adresów oraz szkoły "drugiego domu” - jak go nazywa bratanica Mottego. Ważne punkty, które opisuje na swej drodze Cegielska, to sklepy, składy, zakłady rzemieślnicze, jakie mijała w drodze do domu, odwiedzała - lub widziała na szyldach, których uczyła się czytać. Jakkolwiek więc i Cegielska nie uprawia flânerie, jej krążenie po centrum, przeplatane anegdotami o sobie i znajomych w rolach głównych, zachowuje ślady osobistego doświadczenia.

Warto zauważyć, że wspomnienia wszystkich pisarzy o pochodzeniu robotniczym (M. Rataj, A. A. Łuczaka i A. Scheffel) nie podejmują flâneurowskiej konwencji - koncentrują się na miejscach, nie na ruchu, co wiąże się zapewne z tym, że piesze wędrówki były dla nich nie tyle przyjemną okazją do poznania miasta,

${ }^{17}$ F. Znaniecki, J, Ziółkowski, op. cit., s. 201-206.

18 T. Maruszewski, Pamięć autobiograficzna. Gdańsk 2005, s. 24-26. 
a jedynym dostępnym sposobem na znalezienie się $\mathrm{w}$ docelowym punkcie: $\mathrm{w}$ pracy, szpitalu, szkole, u rodziny. Tramwaj czy dorożka były zbędnym wydatkiem - a jeśli już się nań decydowano, jazda stawała się dużą atrakcją, jak opisują to Rataj, czy Scheffel ${ }^{19}$, podczas gdy dla Zakrzewskiego, Szulca, Cegielskiej - rutyną. Brak u Rataj także tras, szlaków, łączących kolejne punkty; jeśli się takie pojawiają - jak droga z Górnej Wildy na Plac Wolności - to tylko za sprawą konkretnej anegdoty o wędrówce kilkuletniego dziecka po sprawunki i jednym z jego pierwszych zarobków.

W rzeczywistości książki Zakrzewskiego bardziej niż na pamięci opierają się na wiedzy - pozakontekstowej i nabytej w zapomnianych już okolicznościach. Co więcej, w bardziej osobistym Wspominam Poznań Zakrzewski rozpisuje się o politycznych wypadkach $w$ kraju i na świecie, $w$ formie wyliczeń wymienia osoby zasłużone dla Poznania, świadomie rezygnując z osobistego wspomnienia:

Ktoś, kto przebrnął cierpliwie przez lekturę niemal imiennego wykazu ludzi nauki, uznał go zapewne za nadmiernie długi i nużący. Korciło mnie, by przepleść go jakąś dygresją. Czymś, co by go ożywiło, anegdotą, osobistym wspomnieniem. Prawdę mówiąc, mógłbym coś niecoś wykrzesać z zakamarków pamięci lub z zachowanych zapisków. Cały temat rozrósłby się jednak ponad miarę, więc odstąpiłem. (WP, s. 388)

Zakrzewski tym samym czyni jawną hierarchię wartości, ufundowaną na androcentryzmie: sprawy publiczne zdecydowanie górują doniosłością nad osobistym doświadczeniem. Postawa ta jednak podważa sens pisarstwa wspomnieniowego - encyklopedie oraz kalendaria, tworzone przez zespoły autorskie i rzesze współpracowników, są rzetelniejsze w odnotowywaniu istotnych zdarzeń i osób. Dla porównania Szulc starał się zachować równowagę między tymi dwiema sferami: koncentrując swoje wspomnienia ( $w$ większym nawet stopniu niż Zakrzewski) na aktywności zawodowej i społecznej, przedstawiał encyklopedyczne opisy wzbogacone jednak osobistymi uwagami o poszczególnych lekarzach i radcach.

W żadnym z omawianych utworów wspomnieniowych autorstwa kobiet lub pisarzy pochodzenia proletariackiego nie pojawia się perspektywa prezentowana przez Zakrzewskiego (w mniej skrajny sposób także przez Szulca) i zarazem strategia autobiograficzna, zapewne dlatego, że Rataj, Cegielska, Łuczak, Scheffel i Stanisław Grzesiuk jako bierni jedynie uczestnicy życia publicznego (czytelnicy gazet, słuchacze radia) nie poczuwali się do roli kronikarzy historii swojego miasta, pozostawiając ją bardziej zorientowanym i koncentrując się na tym, co im bliskie i dobrze znane ${ }^{20}$. Co ciekawe, nawet Cegielska, żona posła na sejm i jednego

\footnotetext{
${ }^{19}$ Także u Łuczaka pojawia się motyw przechadzki, jako czegoś niedostępnego, bo zarezerwowanego dla tych, którzy nie muszą pracować lub którym praca nie zajmuje całego dnia.

${ }^{20}$ Koncentracja autorek na własnych doświadczeniach może mieć także przyczyny psychologiczne, jak zauważa bowiem T. Maruszewski, pamięć autobiograficzna dziewcząt jest intensywniej ćwiczona w trakcie socjalizacji. Zob. T. Maruszewski, op. cit., s. 137-140.
} 
z najznaczniejszych poznaniaków, pisząc o spotkaniu politycznych przywódców poprzedzającym wybuch powstania wielkopolskiego, ukazuje siebie wciągniętą (i pociąganą) przez bieżące wypadki historyczne i problemy narodowe, zamkniętą jednak w bardzo ograniczającej roli:

$\mathrm{W}$ tym czasie odbyło się $\mathrm{w}$ naszym mieszkaniu zakonspirowane spotkanie wybitniejszych obywateli miasta. Co na nim postanowiono, nie wiem, bo tylko domyślać się mogłam, a mąż mój milczał na ten temat jak zaklęty. [...] Chcąc zadokumentować, mimo niewiedzy, swe osobiste zainteresowanie, udekorowałam świeżo wyprasowanymi chorągwiami piec w salonie. Może ta dekoracja nie miała wiele sensu, ale w tej chwili i w tym nastroju była potrzebą mego serca. (ZMW, s. 241-242)

Narzucona przez płeć społeczno-kulturową rola statystki historycznego wydarzenia, nawet po blisko czterdziestu latach skłania ją do zachowania dyskrecji o swoich domysłach (słusznych czy nie), milczy, sugerując jednak bardzo wyraźnie poczucie niespełnienia. Rola społeczna przypisana Cegielskiej jako kobiecie nie tylko ograniczała jej pole aktywności do sfery towarzyskiej, ale także modelowała krąg tematów, które podejmowała we wspomnieniach.

Rataj, podobnie jak Cegielska (oraz Łuczak i Scheffel), ogranicza się do przestrzeni dobrze jej znanej i emocjonalnie najbliższej: Wildy, łęgów nadwarciańskich i części śródmieścia. W przeciwieństwie jednak do Cegielskiej (i Zakrzewskiego także) nie narzuca jej żadnego porządku, różne miejsca (kolejne mieszkania, miejsca spacerów, rozrywki, pracy) pojawiają się w toku narracji zorganizowanej przez rytm osobistego doświadczenia, naznaczonego bardzo silnie doznaniami cielesnymi i emocjonalnymi. W porównaniu $\mathrm{z}$ narracjami autorów inteligenckomieszczańskich, jakimi są Zakrzewski i Cegielska, u Rataj uderza brak uprzywilejowanych aksjologicznie centrów - nie są nimi ani administracyjnie ważne miejsca, ani (co ciekawsze) dom ${ }^{21}$. O ile jednak Zakrzewski traktował mieszkanie na Ogrodowej jak dom, podobnie jak Cegielska kolejne sześć domostw, w których żyła, Rataj nie miała takiej możliwości, ponieważ brak stałych dochodów uniemożliwiał jej zamieszkanie w sensie Heideggerowskim - w konkretnym lokum. Uzależniona od woli właściciela posesji, pod wpływem podwyżki czynszu musiała się przeprowadzać. W różnicy tej odzwierciedla się opisywana przez Irę Katznelsona zmiana, jaka dokonała się w stosunku do ziemi i mieszkania w kapitalistycznym mieście, które stały się przedmiotem wolnego handlu, co doprowadziło do po-

${ }^{21}$ Scheffel, podobnie jak Rataj, nie odwołuje się do powszechnej aksjologii przestrzeni Łodzi, w jej wspomnieniach wyraziste są jednak uprzywilejowane punkty, tworzące prywatną mitologię przestrzenną: arkadyjskie podwórko z centralną „wielką plompą” (pompą) - miejscem zabaw i źródłem wody dla całej polsko-niemiecko-żydowskiej społeczności zamieszkującej okoliczne kamienice. Na tę prywatną mitologię dzieciństwa nakłada się także wizja zgodnego, a nawet przyjaznego współegzystowania trzech nacji i trzech wyznań w międzywojennej Łodzi. Por. T. Czerska, op. cit., s. 208 oraz K. Sołecka, Baśń o Wielkiej Plompie, w: A. Scheffel, op. cit., s. 110-111. 
wstania dzielnic o charakterze klasowym ${ }^{22}$, usytuowanych zazwyczaj na obrzeżach miasta, zepchniętych na jego margines. Warto także wspomnieć, że w latach 20. XX wieku zauważano ten proces i próbowano mu się przeciwstawiać, przynajmniej w sferze symbolicznej. Publicystyka i literatura coraz żywiej interesowała się właśnie przedmieściami, o czym pisała Rybicka, omawiając prozę dokumentu społecznego oraz karierę - „Przedmieścia” jako grupy literackiej, ale także terminu na oznaczenie społecznych i kulturowych wykluczeń2 ${ }^{23}$. Naprzeciw zagrożeniom społecznym i kulturowym związanym z marginalizacją części dzielnic i dyskryminacją ich mieszkańców w tradycyjnym mieście wyszedł także Oskar Hansen, od lat 60. XX wieku planując zamiast nich linearne systemy ciągłe. Związek między waloryzacją przestrzeni, a stanem posiadania i klasą społeczną bardzo dobrze ilustruje historia przeprowadzek rodziny Rataj w jej wczesnym dzieciństwie. Dopóki matka pracowała, rodzina mieszkała w ścisłym centrum, na ul. Św. Marcin; wraz z postępującą degradacją społeczną przeprowadzała się coraz dalej: początkowo na Wildę (dzielnica robotnicza), później w jej głąb, aż na łęgi nadwarciańskie, gdzie mieściło się osiedle bezdomnych.

Poznań ujmowany w kategoriach przestrzennych u Rataj inaczej niż Zakrzewskiego, nie pokrywa się z terenem administracyjnie uznanym za miejski. Liczba wspólnych im miejsc także jest nieliczna - należy do nich nadwarciańska plaża. Oboje poznaniacy różnie ją jednak cenią. W Przechadzkach po Poznaniu zostaje ona zdyskontowana przez nadmorską (PPP, s. 240), podczas gdy dla Rataj pozostaje łatwo dostępną i ulubioną przestrzenią odpoczynku (ale i pracy) (GM, s. 122) - być może dlatego tak cenioną, że w przeciwieństwie do Zakrzewskiego nigdy pisarka nie miała dostępu do innych rozrywek (tenisa, gry w piłkę, wycieczek)24.

Innym wspólnym miejscem poznaniaków, zważywszy że oboje byli wielbicielami dziesiątej muzy, mogłyby być kina. Zakrzewski zachwycał się jednak nowoczesnością "Słońca” i elegancją jego gości, poznanianka z niechęcią natomiast wspominała złe warunki higieniczne i niewybredną publiczność "pchlich kin”. Także repertuar różnił te kina: ambitniejszy pozostał Rataj nieznany, w „pchlich kinach" grywano głównie filmy sensacyjne i farsy (zob. GM 50-52; 99-100 oraz WP, s. 95-96). Rataj korzystała także z atrakcji oferowanych przez działające od 1934 r. Kino Oświatowe (GM, s. 173), oferujące bezpłatne bilety dla biednych i bezrobotnych 25 .

22 I. Katznelson, Marxism and the City. New York 2004, s. 226-227.

${ }^{23}$ Zob. E. Rybicka, op. cit., s. 265-270.

${ }^{24}$ Warto wspomnieć także o różnicach klasowych widocznych w podpoznańskich letniskach: Szulc opisuje Puszczykowo jako ostoję poznańskiego mieszczaństwa, biednym pozostawała dalece mniej atrakcyjna (i odleglejsza od Poznania) Kobylnica, gdzie Rataj jako uczestniczka kolonii dla dzieci organizowanych przez towarzystwo Stella spędzała wakacje. Por. WPL, s. 85-86; GM, s. 162-164).

${ }_{25}$ Zob. M. Hendrykowska, M. Hendrykowski, Film w Poznaniu i w Wielkopolsce 1896-1996. Poznań 1996, s. 16. 
Rozrywki towarzyskie, jakim się oddawali, choć podobne, miały dla nich zupełnie inne znaczenie. Zakrzewski (podobnie jak Szulc, Waldorff i Cegielska) chadzał na bale i potańcówki organizowane w prywatnych mieszkaniach lub dużych salach (Biała Sala „Bazaru”, aula uniwersytetu, „Palais Royal”). Stanowiły one nie tylko rozrywkę, ale i pełniły ważną społeczną funkcję - były symbolicznym momentem wkroczenia $\mathrm{w}$ dorosłość, a także dawały młodzieży z tej samej warstwy szansę, by lepiej się poznać. Dla męskiej młodzieży proletariackiej zabawy taneczne, nawet jeśli odbywały się $\mathrm{w}$ daleko mniej eleganckiej scenografii, miały podobne znaczenie. Stanisław Grzesiuk opisuje wyprawę na dancing w kategoriach rytu przejścia: młodzi mężczyźni tańcząc, pijąc, walcząc o dziewczyny i bijąc się dowodzą swego męstwa - w tym środowisku określanym mianem kozactwa26. Dla dziewczyny jednak, jeśli nawet jest ona diablicą, jak Rataj, wyprawa na taką zabawę wygląda odmiennie:

- Co sobotę i niedzielę są zabawy przy Drodze Dębińskiej.

- A potem po mordzie, co?

- E, gdzie tam, za co?

- Czemu bujasz? Jak dziewczyna nie da, to bidna, no ja już coś o tym słyszałam, tam łażą przeważnie grandziarze, alfonsy i kacpy.

- Przecież możesz parę kawałków zatańczyć, a potem po prostu zwiać. (GM, s. 226)

Zarówno dla Rataj, jak i Grzesiuka potańcówka nierozłącznie związana jest z interakcjami między płciami, jednak to, co dla niego będzie elementem rytu inicjacyjnego (opisywanego też dużo łagodniej niż przez poznaniankę), dla niej stanowi przemoc na tle erotycznym - choć kulturowo usankcjonowaną, pozbawioną naddatku semantycznego, a tym bardziej symbolicznych i społecznych wartości.

W kontekście pisarstwa wspomnieniowego Zakrzewskiego zwraca także uwagę uprzywilejowanie przez pisarzy o korzeniach proletariackich miasta jako społeczności, nie zaś całości architektonicznej czy jednostki terytorialnej. Być może to encyklopedyczna technika uprzywilejowująca faktograficzne informacje sprawia, że Zakrzewski nie zauważa codziennego oblicza Poznania, zwracając uwagę na to, co stosunkowo najtrwalsze: architekturę i bieg ulic, co wskazuje także na supremację wzrokowego poznania. Jeśli pojawiają się u niego nazwy składów - to tych najelegantszych i najbardziej sławnych (sklep przy Starym Rynku), niezwykle rzadko natomiast wspomniane zostają bardziej pospolite miejsca jak np. zakład szewski, do którego matka odnosiła buty do naprawy. Co jednak znaczące, Zakrzewski nie uznaje za stosowne podać nazwiska szewca (lub go nie pamięta). Cegielska, reprezentująca tę samą klasę, koncentruje się natomiast na sklepach i ich asortymencie, wymieniając nazwiska właścicieli lub sprzedawców, podając ich krótkie charakterystyki, opis wyglądu lub zwyczaje - tak jak np. w przypadku

${ }^{26}$ S. Grzesiuk, Boso, ale w ostrogach. Warszawa 2008, s. 66-71. 
p. Miczyńskiej, właścicielki składu nabiałowego na ul. Wrocławskiej, która „W nieskazitelnie białym fartuchu często suszyła bieliznę na płaskim dachu swego domu" (ZMW, s. 67).

Miasto w społecznym wymiarze u Zakrzewskiego jest prawie całkowicie mieszczańsko-inteligenckie - robotnicy, bezrobotni, bezdomni zostali $\mathrm{w}$ zasadzie wyrugowani $\mathrm{z}$ tego literackiego, nostalgicznego Poznania lat międzywojennych. Zakrzewski wspomina o nich tylko bardzo ogólnie i rzadko (a warto przypomnieć, że przez całe 20-lecie Poznań zmagał się z gigantycznym kryzysem mieszkaniowym, a bezrobocie dotyczyło 18-20 tysięcy mieszkańców).

Co ciekawe jednak, o ile dla Zakrzewskiego Poznań jest miastem jednoklasowym, co więcej - składającym się w zasadzie tylko z wybitnych osobistości (profesorowie, lekarze, społecznicy, artyści, dziennikarze, politycy), nie można tego samego powiedzieć ani o Poznaniu Rataj, ani nawet Cegielskiej27. Choć Poznań jako całość społeczna jawi się tej pierwszej głównie przez pryzmat robotników, służby i bezrobotnych, do sfery tej przenikają osoby z wyższych klas społecznych: niekiedy w związku z działalnością charytatywną, duszpasterską, nadzorczą (policja), równie często jednak w celach zdecydowanie mniej szczytnych i czasem nielegalnych. Rataj opisuje sytuację, która zdarzyła się jej, gdy pisarka miała trzynaście lat:

obok przysiadł się jakiś poważny gość. Zaczął jak to zwykle bywa, zagadywać o wszystkim i o niczym, aż wreszcie drogą okrężną doszedł do zwykłej rzeczy. Tą razą nie byłam na flirt nastawiona i raczej zła na przerwanie samotności, więc odpowiedziałam niegrzecznie.

- Czego pan tak kołuje? - spytałam zaczepnie. - Wiem przecież, o co panu chodzi.

$[\ldots]$

- Co ty też wygadujesz, a dawno już się tak puszczasz?

- Wcale się nie puszczam [...]

- No to skąd taka mowa? - Facet jest coraz więcej zdziwiony

- To przez was, wy wszyscy tego mnie codziennie uczycie. Pan i panu podobni. Macie starych bab dosyć, to chcecie dziewuszki, a wiecie, jak je kupować, choćby nawet za dwa, pięć czy dziesięć złotych.

- Bo prędzej czy później i tak schodzicie na tą drogę.

- Myli się pan, a czemu nie psujecie tych waszych lepszych dziewczynek? Och, je ochraniacie, bo do ślubu mają być niewinne i jeszcze im się do tego dodaje majątek, prawda? (GM, s. 192)

${ }^{27}$ Choć ta ostatnia, zgodnie z przekonaniami wpojonymi jej przez ojca („,bliższa jest mu chwaliszewska biedota, niż obce żywioły górnego miasta", ZMW, s. 31), wspomina służbę i osoby z niższych klas społecznych, czyni to jednak z rzadka i paternalistycznie: Tak się w owych czasach zabawiono w niedzielne południa pozornie niewinnie, czasem trochę długo, a w kuchni Anusia Deręgowska, czy też Jagusia Kaniewska załamywały ręce, siedząc na skrzyni od węgla, bo rostbef akurat od Zakrzewicza zamieniał się w podeszwę [...]", ZMW s.164. 
Ten obszerny fragment dobitnie wskazuje, że podtrzymywaniu mieszczańskiej moralności służyło wyłączenie spod jej zasad proletariatu ${ }^{28}$. O ile jednak mieszczanie mogli się zniżyć $\mathrm{w}$ takich celach, $\mathrm{w}$ drugą stronę, jak pokazują wspomnienia Zakrzewskiego, granica między klasami nie była przepuszczalna - mężczyzna z jego klasy nie zauważał służących, drobnych rzemieślników, robotników, podobnie zresztą jak Szulc, wspominający tylko jedną „babę", którą zwolnił z powodu alkoholizmu; o jej poprzedniczkach ani następczyniach jednak nie wspomniał (WPL, s. 108).

Homogeniczność miasta przedstawionego we Wspominam Poznań i Przechadzkach po Poznaniu ujawnia się także w perspektywie wyznaniowej i narodowościowej. Zbory protestanckie i synagogi są, co prawda, wymieniane, ale wydają się puste, ponieważ nie ma mowy o odwiedzających je wiernych, tak jakby były one jedynie pamiątką po pruskiej przeszłości miasta, podczas gdy polski Poznań miałby być całkowicie katolicki. (Cegielska, dla porównania, pisze natomiast także o Polakach wyznań protestanckich - choć podejrzliwie, zawsze wzmiankując czy religia pociągnęła za sobą zniemczenie). Podobnie niewrażliwy na obecność mniejszości niemieckiej jest Zakrzewski, wspominając o niej jedynie w dwóch fragmentach: gdy pisze o modzie na polszczyznę wśród Niemców, odzwierciedlającej się w opowieści o pannie Sieg, która kazała się nazywać Sieżanką, co Zakrzewski ironicznie kwituje, że inny prefiks dodany do jej panieńskiego nazwiska wywoływałby nieprzystojne żarty. (Nota bene Cegielska przytacza anegdotę opartą na podobnym koncepcie, ale dotyczącą nazwiska Żyda, ZMW, s. 75, por też WPL, s. 103). Druga opowieść dotyczy natomiast żałosnego końca redaktora niemieckojęzycznego dziennika, który zmarł spadając ze schodów w stanie upojenia alkoholowego. O czytelnikach tej gazety Zakrzewski jednak milczy. Z drugiej strony nie zapomina wspomnieć o detalach architektonicznych takich jak popiersie Kopernika ukryte na szczycie kamienicy na ul. Kopernika (PPP, s. 116-117), by zamanifestować polską tożsamość tak właściciela kamienicy, jej budowniczego, jak i miasta. Przykład Rataj, urodzonej $\mathrm{w}$ mieszanym polsko-niemieckim i katolicko-luterańskim małżeństwie, która w związku z tym podlegała zarówno ostracyzmowi z powodu niemieckiego pochodzenia, jak i działalności katechizacyjnej ze strony Kościoła Katolickiego udowadnia jednak, że Poznań nie był tak jednolity pod względem narodowościowym i wyznaniowym jak chce to pamiętać związany we wczesnej młodości z Młodzieżą Wszechpolską Zakrzewski. Co więcej, napięcia, które on przemilcza, pojawiają się $\mathrm{w}$ jego wspomnieniach implicite - w postaci nielicznych i niechętnych niemieckiej mniejszości wzmianek w Przechadzkach po Poznaniu.

Portret miasta to także jego język - Zakrzewski dostrzega odmienność językową mieszkańców Poznania, ale, co istotne, sam nie posługuje się gwarą. Z rzadka jedynie ją cytuje:

28 Por. S. de Beauvoir, Druga pteć. Przeł. G. Mycielska, M. Leśniewska. Warszawa 2007, s. 125. 
Kobiety gaduły potrafiły, spotykając się paplać całymi godzinami o wszystkim i o niczym, a to, że dajmy na to "przyjechał wuja z Hanoweru”, „w antrejce na ryczce miałam stać wymborek, ale ktoś go dygnął”, „musze już iść, bo trzeba zrobić butersznytki dla wszystkich gzubów", i tak dalej. (WP, s. 129)

Przytacza także sytuację z przystanku tramwajowego „Szpycnij, dwie bimby jadom do kupy” lub wypowiedź tramwajarza „Franek, przełóż no te wajche, bo jadymy bez teatralke” (PPP, s. 319). W tych przytoczeniach, niepozbawionych dozy folklorystycznego zainteresowania i zdziwienia odmiennością mowy poznaniaków od literackiej polszczyzny, można dostrzec proces modernizacji obrazu miasta w literaturze, opisywany przez E. Rybicką ${ }^{29}$. Podobny, choć - jak się wydaje - mniej zdystansowany, stosunek do gwary miała Cegielska (zob. ZMW, s. 71). Zdecydowanie bardziej krytycznie odnosi się do niej natomiast słabiej związany z Poznaniem Waldorff, który nie decyduje się nawet na cytat z gwary, uznając ją za zdradę polszczyzny (i polskości):

Społeczeństwo poznańskie, tak dzielne $\mathrm{w}$ walce o polski stan posiadania, ani się orientowało, ile przecież traci skutkiem niewidocznego, aliści codziennego, rozsądzającego parcia niemczyzny na język polski [...] tymczasem i gwara domowa ulegała powolnym zniekształceniom skutkiem trwałego sąsiadowania z językiem zaborców. (F, s. 20-21)

Co ciekawe, Rataj traktuje gwarę nie w kategoriach narodowościowych czy folklorystycznych, a stricte klasowych: jako czynnik stygmatyzujący i uniemożliwiający awans społeczny:

Tak bez nauki nie ma nic, lecz na myśl o geografii czy polskim cierpła mi skóra. To było coś jak wielka góra, a nikt nie umiał mi powiedzieć jak się na nią dostać. Kto miał mi pomóc? Czy matka kalecząca język niesłychanie, jak wszystkie Niemki, co się przyuczą? Czy Franka znająca typową poznańską gwarę i wyśmiewająca się z lepszych? Czy też moje sąsiadki mówiące „wymborki”, "śruper" na szczotkę, "śrupy" na konia, „leberka" na wątrobiankę i "gutalina" na pastę do butów? Chciałam do lepszych, to prawda, lecz ich nie zawsze rozumiałam... (GM, s. 173-174)

Doniosłe znaczenie ma wobec powyższych stwierdzeń fakt, że Rataj, mając świadomość, że język, którym się posługuje, zdradza jej pochodzenie społeczne, zdecydowała się napisać wspomnienia. Ta decyzja i sama autobiografia, mają wobec tego wymiar manifestu. W przywiązaniu do gwary oraz zaangażowanej ideologicznie konstrukcji Zaułków grzesznego miasta można, podążając za I. Katznelsonem, dopatrywać się aspektu lingwistycznego i kulturowego tożsamości klasowej ${ }^{30}$, na której dopiero ufundowane mogą być zbiorowe działania.

\footnotetext{
${ }^{29}$ E. Rybicka, op. cit., s. 269-270.

${ }^{30}$ I. Katznelson, op. cit., s. 208-209.
} 


\section{WALKA O POZNAŃ}

Dwie odmienne wizje Poznania lat międzywojennych to jednak nie tylko starcie dwóch perspektyw, zdeterminowanych przez czynniki klasowe i genderowe, ale także ślad ideologicznej batalii o władzę nad społeczną wyobraźnią. Opublikowanie po raz pierwszy po prawie siedemdziesięciu latach Przechadzek po mieście w 1957 stanowiło swoiste preludium do tej potyczki: przypominało tekst sławny, kanoniczny - ale dotyczący rzeczywistości ubiegłego stulecia. Międzywojenną historią Poznania można było jeszcze zawładnąć: pisane w połowie lat 50. (i odpowiednio zredagowane) Zaułki grzecznego miasta pisane jak wspomnienia XIX-wiecznych brytyjskich robotnic „[...] bardziej w celach komunikacyjnych niż introspekcyjnych lub estetycznych: by utrwalić dla kolejnych pokoleń minione doświadczenia, by zarobić pieniądze lub dla własnej przyjemności" 31 , bardzo dobrze odpowiadały tym celom można je było postrzegać jako dosadną krytykę społeczeństwa burżuazyjnokapitalistycznego, czego nie omieszkała uczynić współczesna krytyka32.

Kontekst historyczno-literacki nie podważa jednak podmiototwórczego charakteru tej autonarracji, jak bowiem stwierdziły autorki Women and Autobiograohy autobiograficzna literatura bardzo często powstawała pod wpływem wymogów, nacisków instytucjonalnych lub pod presją i kontrolą władzy nieformalnej33. $\mathrm{Z}$ drugiej strony warto także zwrócić uwagę, że międzywojenne zainteresowanie "przedmieściami" zaowocowało w sferze wspomnień Życiorysem własnym robotnika Jakuba Wojciechowskiego (1930 r.), jego kobiecy odpowiednik, Pamiętnik matki Marcjanny Fornalskiej, pojawił się dopiero w 1960. Konieczne więc było trzydzieści lat (i inny ustrój), by dostrzeżono, że na symbolicznych przedmieściach kultury i społeczeństwa znajdują się nie tylko robotnicy, ale i robotnice, dyskryminowane podwójnie: jako proletariuszki i jako kobiety, co oczywiście nie wyklucza instrumentalnego i ideologicznego wykorzystania ich wspomnień.

Walka o wyobrażenie międzywojennego Poznania została już rozstrzygnięta. Mimo niewątpliwego sukcesu wydawniczego i pochlebnych (w tym Jarosława Iwaszkiewicza), a niekiedy i entuzjastycznych (Józefa Ratajczaka) recenzji, wspomnienia Rataj nie stały się częścią poznańskiego kanonu. Głos z marginesu został zmarginalizowany. A szkoda, bo proletariackie i kobiece oblicze Poznania, jako rewers tego mieszczańskiego i męskiego, wydaje się nieodzowne.

31 R. Garnier, The Literary Standard, Working-Class Autobiography and Gender, w: S. Smith, J. Watson (Eds), Women, Autobiography, Theory. A Reader. Madison, Wisconsin 1998, s. 265.

32 Pomijam tu problem ideologicznych manipulacji wspomnieniami Rataj, o czym pisałam w innym miejscu Zob. M. Bednarek, Autoportret na tle miasta. Opowieść o Marii Rataj i jej wspomnieniach, „Kronika Miasta Poznania. Poznanianki” 2011, nr 1, s. 232-235.

${ }_{33}$ Zob. T. Cosslett, C. Lury, P. Summerfield, Introduction, w: Feminism and Autobiography, Texts, Theories, Methods. Red. T. Cosslett, C. Lury, P. Summerfield. New York 2000, s. 17. Zob też. L. Stanley, From 'Self-made Women' to 'Women/s Made Selves', w: ibidem, s. 43. 


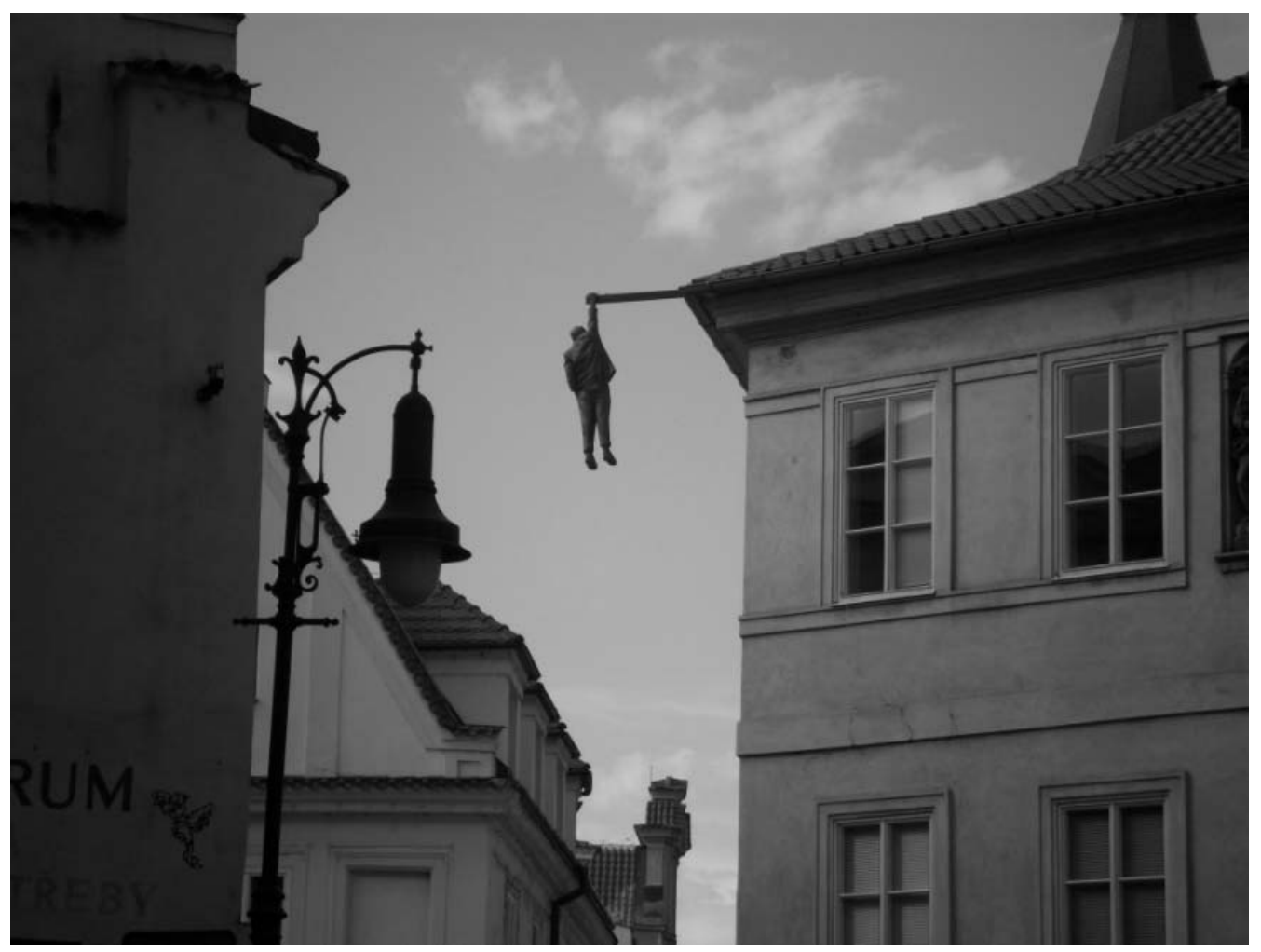

